\title{
Progress and mechanism of breaking glycoconjugates by glycosidases in skin for promoting unhairing and fiber opening-up in leather manufacture. A review
}

\author{
Fengxiang Luo ${ }^{1,2}$, Xiang Zhong ${ }^{1,2}$, Mengchu Gao ${ }^{1,2}$, Biyu Peng ${ }^{1,2^{*}}$ and Zhongzhen Long ${ }^{3}$
}

\begin{abstract}
The glycoconjugates, herein glyco-proteins, existing in animal skins are closely related to the effectiveness of unhairing and fiber opening-up. Glycosidases have been used in leather making processes to reduce pollutants and improve leather quality. But the selection of glycosidases is still blind because the related mechanisms are not well understood yet. Hence, the animal skin structures and glycoconjugates components, the advances in the methods and mechanisms of removing glycoconjugates related to unhairing and fiber opening-up in leather manufacture, the kinds, compositions, structures and functions of typical glycoconjugates in skin are summarized. Then the approaches to destroy them, possible glycosidases suitable for leather making and their acting sites are analyzed based on the recognition of glycoconjugates in skin and the specificities of glycosidases toward substrates. It is expected to provide useful information for the optimization of glycosidases and the development of new enzymes and the cleaner technologies of unhairing and opening up fiber bundles assisted by glycosidases.
\end{abstract}

Keywords: Glycosaminoglycan, Proteoglycan, Glycosidase, Unhairing, Fiber opening-up

\section{Introduction}

As the relationship between human beings and the environment are more concerned, the cleaner and highefficient leather production is an irresistible trend in this scenario. The leather making process is aimed at converting the raw animal skins, a byproduct of the animal husbandry and slaughter industry, into not only the high-quality leather but also the eco-benign products [1]. Enzymes, a kind of the promising cleaner materials, are expected to change the negative image of leather manufacturing by reducing the environmental pollution produced by the heavy application of polluting chemicals in the beamhouse $[2,3]$. The main purposes of

\footnotetext{
* Correspondence: pengbiyu@scu.edu.cn

'Key Laboratory of Leather Chemistry and Engineering of Ministry of

Education, Sichuan University, Chengdu 610065, China

${ }^{2}$ National Engineering Laboratory for Clean Technology of Leather

Manufacture, Sichuan University, Chengdu 610065, China

Full list of author information is available at the end of the article
}

conventional beamhouse processes are to remove the unwanted substances in skins and open up the collagen fibers by using acids, alkalis and salts [4]. The liming and hair-dissolving processes based on the use of sulfides and lime to achieve hair removal and fiber opening-up are the major sources of pollution. Thus, the substitution of the conventional liming process with cleaner chemicals and easier methods is a goal for the leather industry. Enzymatic unhairing and opening up fiber are the developing tendencies [5, 6].

Despite there are copious literatures about the application of enzymes in leather production, few of biotechnologies are widely used on an industrial scale except for the bating process based on pancreatic enzymes. So far, the mechanisms of enzyme unhairing and fiber opening up are still not clear and fully understood $[7,8]$. For protease unhairing, it is very hard to solve the problem of keeping the balance of the complete unhairing and good 
grain layer [9]. Although the effectiveness and safety of glycosidases on promoting unhairing and fiber openingup have been verified, the related mechanism is also still under the veil, including the structure of the targeted materials, kinds and specificity requirements for enzymes, and cleavage sites and ways of enzymolysis [10]. Nowadays with the development of hotspot in glycoconjugates, especially the proteoglycan (PG) and glycoprotein (GP) [11], more knowledge and study of the related interfibrillar substances in skins will help to understand the mechanism of unhairing and fiber opening up assisted by glycosidases, and develop high-efficient biotechnologies for leather-making [12].

Aiming to understand the related mechanisms and provide the useful information for the optimization of glycosidases and development of cleaner technologies of unhairing and fiber opening-up assisted by glycosidases, the advances in the methods and mechanism of removing glycoconjugates, the kinds, compositions, structures and functions of typical glycoconjugates in skin are summarized, and the approaches to destroy them and possible acting sites of glycosidases are analyzed according to the structures of glycoconjugates in skin and the glycosidase specificities, and then the suitable glycosidases for leather making are suggested.

\section{Animal skin and hair follicle structures}

There are many kinds of glyco-protein conjugates indispensable to the skin, although their contents are rather low, accounting for about $0.70 \%$ and $0.58 \%$ of the total weight of wet cattle hide and sheepskin, respectively [13]. The glyco-protein conjugates play very important roles in cell morphogenesis, proliferation, growth and signal transduction, especially maintaining the fiber structure and physical and mechanical properties of skin, keeping the moisture, promoting materials exchange among organizations, regulating ion contents in skin tissue, and preventing pathogens, bacteria and foreign materials [14]. Glyco-protein conjugates in skin are mainly composed of proteins and polysaccharides. According to the difference of proteins and saccharides, they can be classified as glycoprotein (GP) and proteoglycan (PG), respectively. PGs consist of a core protein heavily glycosylated by the unbranched long saccharide chains called glycosaminoglycan (GAG), while GPs contain a few saccharides.

\subsection{Structure of animal skin}

Animal skins and hides, commonly pigskins, sheepskins, goatskins and cattle hides, are the raw materials of leather industry. The skin can be divided into three layers in histology according to their structure and function, i.e. epidermis (upper layer), dermis (middle layer), and subcutaneous tissue (flesh layer). In different layers, the distribution and content of glyco-protein conjugates are different. The sketch of skin is presented in Fig. 1.

Epidermis, the first protective barrier of the skin, is made up of gradually keratinized multilayer cells [16]. The PG and GP in epidermis mainly exist in the basal layer and cellular matrix in the form of sticky and amorphous ground substances.

The basement membrane is a thin fibrous tissue of the extracellular matrix, tightly connecting the epidermis and dermis [17]. It consists of an underlying network of collagen IV fibrils, coated by various PGs, such as perlecan, laminin, and anchored by collagen VII and fibronectin $[18,19]$.

In the leather making process, the epidermis as the permeability barrier and the basement membrane as an adhesive need to be removed. The epidermis and basement membrane are mainly broken in the unhairing process [20-22].

The dermis accounting for about $90 \%$ of skin lies under the epidermis. After combining with tanning agents, the dermis determines the properties of the final leather. It is composed of a few cells such as fibroblasts and mastocytes, a large quantity of fiber components and extrafibrillar matrix. The collagen fibers are hierarchically structured as a skeleton. The other elastin and reticulin fibers help to wrap and protect the skeleton. The viscous and amorphous extrafibrillar matrix cement these fibers.

The fundamental material in the dermis is collagen, and its structure is of the essence. Three peptide chains form a collagen molecule by the involvement of a righthand helix [23]. Then the collagen microfibril is arranged by several collagen molecules with the quarter staggered pattern. Many microfibrils are cemented into collagen fibrils by PGs and GPs, and then many fibrils are assembled to fibers. Hundreds and thousands of fibers come closer to form fiber bundles. Then fiber bundles with different sizes are woven into a threedimensional network structure in different directions. The filamentous elastin and reticular fibers surround hair follicles and exist in blood vessels wall. The spaces between fibers are filled with the cementing materials, mainly consisting of PGs and GPs, making the fibers tightly and orderly arranged. The content of proteoglycans in the skin is found to be $0.4 \%-0.8 \%$. The PG content of the grain layer is about twice of the reticular layer attributing to the larger superficial area of the finer fiber in the grain layer than its case in the reticular layer [24].

\subsection{Structure of hair follicle}

The animal skins and hides are usually covered and protected by hairs firmly anchored in the hair follicles deep in the dermis [25], as illustrated in Fig. 1. To remove the 


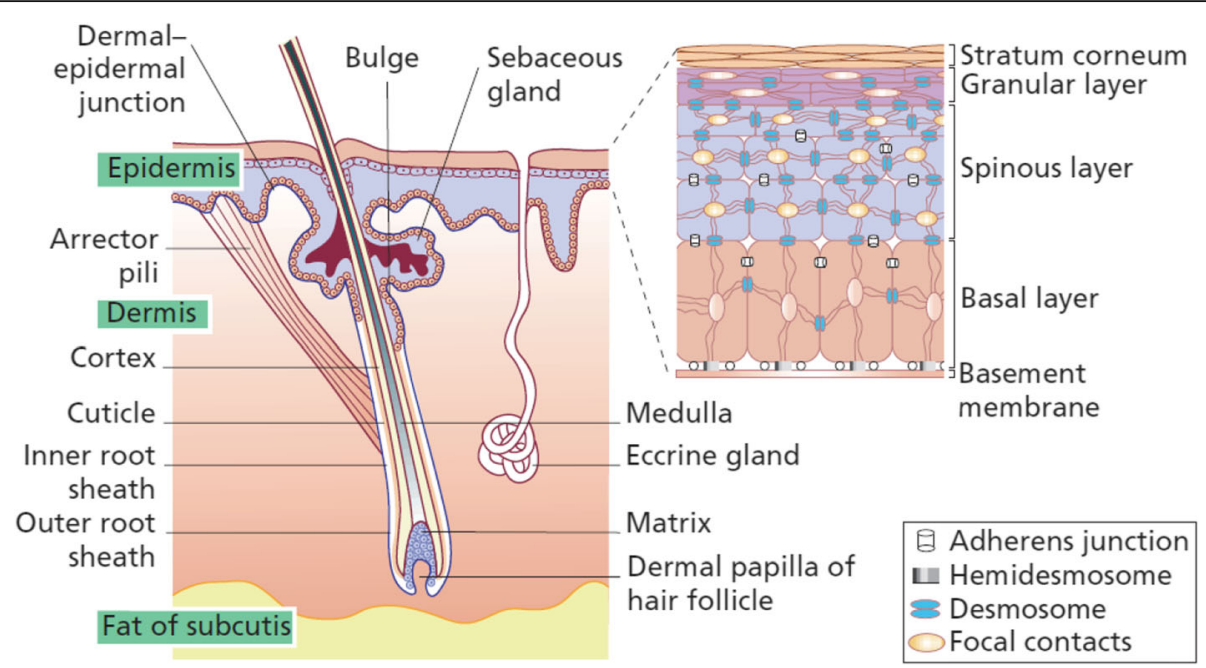

Fig. 1 The sketch of skin. Reprinted from ref. [15], Copywright (2004), with permission from Blackwell Publishing Ltd.

hair from skin, structure of hair follicle needs to be destroyed.

Hair bulb like an onion is where the hair grows by proliferation and differentiation of epidermis cells upward. The hair follicle, which is made up of the collagen, elastin and PG, holds and catches the hair shaft. The inner root sheath outside the hair shaft is the sunk epidermis made by the keratinized epidermal cells. Then the outer root sheath comprises the suprabasal and basal layer of the epidermis. Dermis sheath outlines the epithelium of the hair follicle. There are abundant PGs in the papilla, root sheath and dermis sheath, which are mandatory for the growth cycle of hair.

As mentioned above, the cell spaces of the epidermis, corium and hair bulbs are cemented by the sticky and amorphous interfibrillar substances, mainly including PGs and GPs, which are also called mucin and mucoid in 1940s. These substances are not only the components of skin, but also the key factors to keep the mechanical properties of skin [26]. It has been well recognized that the existence of these substances is closely related to the leather making processes and the quality of leather, such as the effectiveness of unhairing and fiber opening-up. Hence, there is much work focused on promoting leather processes and improving leather quality by the ways of removing these kinds of protein-saccharide conjugates, including chemical and biochemical methods, as described below.

\section{Advances in the methods and mechanism of removing glyco-protein conjugates related to unhairing and fiber opening-up in leather manufacture}

Chemicals, i.e., salts, acids and alkalis are used to remove the unwanted substances except for the collagen, such as scurf, hairs, fats and the interfibrillar substances in the traditional beamhouse processes, thus resulting in heavy pollution. In the conventional leather manufacturing process, scurf, blood, dirt and soluble protein in skin are removed by surfactant and sodium carbonate in soaking process. The hair shafts, epidermis and basement membrane are destroyed and even dissolved by sodium sulfide and lime. Consequently, the hairs are separated and removed from the dermis. As far as opening up fiber bundles of skin is concerned, lime and sulfide provide strong alkali condition to make fiber bundles swell by ionization of acidic groups of the side chains of collagen molecules, such as glutamic and aspartic acids. The electrostatic repulsion of negative charges between collagen molecule chains extends their space distance, consequently, the microfibrils, fibrils and fibers are separated. The removal of interfibrillar substances, i.e. PGs or GPs, probably from the cleavage of the linkage of protein and saccharide in strong alkali condition, is closely related to the performances of the leather, especially the softness [27-29]. But it is also reported that only about half of the PGs with the GAG chain of dermatan sulfate (DS) is removed in the liming process, and the incomplete removal leads to the opening-up of fibers not enough for soft leather $[24,30]$.

Besides the defects of nonsufficient removal of the hair roots and interfibrillar substances, the conventional liming process produces $70 \%$ of pollutants in leather manufacture. To change the negative image of heavy environment pollution and increase production efficiency, the development of cleaner and more efficient methods for unhairing and fiber opening-up is vital.

As early as the 1940-1950s, leather chemists and technologists believed that the mucin and mucoid, the sticky and amorphous substances in animal skins, composed of 
proteins and saccharides and located in the interfibrillar substances, maybe the adhesives between hair papillae and hair roots, outer hair root sheaths and hair shafts, and among collagen fibers. They not only help to bind the hair papillae and follicles, but also bind the collagen microfibrils to form fibrils, fibers and fiber bundles. Therefore, it is speculated that the destruction of these materials is benefit for achieving fiber opening-up and hair removal [31], and some glycosidases with the ability to hydrolyze glycosidic bonds of mucin and mucoid, such as hyaluronidase, amylase, pectinase and glucoamylase, are used in soaking, liming, unhairing and bating processes [32, 33].

\subsection{Glycosidase assisting soaking}

Aiming to rehydrate of the skin in soaking process completely, it is necessary for removal of the unwanted non-collagenous substance including glyco-protein conjugates by enzymes. Bowes et al. found that using the mucolytic enzyme hyaluronidase in soaking was an effective method to remove the interfibrillar fluids in animal skin in 1951 [34]. Hyaluronidase was also used to help the rehydration of skin in soaking process because hyaluronidase could remove the hyaluronic acid from the interfibrillar matrix [35]. Botev used an amylase from bacteria for soaking dried wool lamb skins. Many researchers support the opinion that using carbohydrases can break down the carbohydrates in the interfibrillar substances, thus it can assist the rehydration of salted and dried skin, decrease soaking time, promote the penetration of chemicals into the skin in the following processes, and improve the physical and mechanical properties of leather, especially softness [36-38]. The common glycosidases used in soaking include $\alpha$-amylase, $\alpha$-galactosidase, glucoamylase and hyaluronidase. In addition, cellulase, xylanase, lactase and their mixture could effectively break the dung of animal skin by breaking the cellulose, hemicellulose and lignin $[39,40]$. Most of the reports only involved in the effects of some certain carbohydrases on assisting soaking, and the availability of enzyme action was simply judged by determining the content of sugar in soaking bath. The relative mechanisms, i.e., the exact targets, cutting sites and work ways of glycosidases, the types of optimum enzymes and so on, were seldom mentioned, because the glyco-protein conjugates in the interfibrillar matrix are multifarious, and different carbohydrases or glycosidases have different specificities on glucosides [41].

\subsection{Glycosidase assisting opening up fiber bundles}

The widely accepted opinion is that the removal of PGs is closely related to the effect of fiber opening-up. Leather with well opening-up of fibers exhibits better comprehensive performances [42]. It is also well accepted that the good fiber opening-up requires to reduce the content of the dermatan sulfate (DS), the typical glycosaminoglycan (GAG) chain of PG, in skin lower than $0.2 \%-0.3 \%$ (based on the dry collagen weight). However, only less than $4 \%$ of DS is removed in the conventional soaking process and about half of the DS is removed in liming process [30]. Enzymes or extracts of animals or plants with the amylolytic activity were used for unhairing, meanwhile improving the softness of leather [43-45]. The leather treated by $\alpha$-amylase showed better softness and comparable physical and mechanical properties to that in the conventional liming process [46-48]. $\alpha$-amylase could hydrolyze $\alpha$-glucosidic bond of carbohydrates in skin and increase content of the reducing sugar in the bath. But there were still glyco-protein conjugates left in skin treated by $\alpha$-amylase, which could be observed by the stained method of Periodic acid-Schiff according to our research. The effect of fiber opening-up with $0.5 \%$ of $\alpha$ galactosidase for $30 \mathrm{~min}$ was better than $10 \%$ of lime for $48 \mathrm{~h}$, and the removal ratio of total sugar and proteoglycan was $15 \%$ higher than that of the conventional method, even reached to $90 \%[49,50]$. It was speculated that galactosidase could help fiber opening-up by removing the oligosaccharide moieties of $\alpha 1$ or $\alpha 2$ chain in collagen molecules. Therefore, collagen fiber bundles with sugar free showed increased void space for easy penetration and enhanced interaction of collagen functional groups with tanning chemicals [49]. Xylanase was also used to help the penetration of chemicals into the skin by breaking the melanin and adhering materials existing between the epidermal and melanin layer, and the cleaner grain was obtained [50]. The effectiveness of glycosidases promoting the fiber opening-up can be attributed to the two aspects: the one is that glycosidases can break proteoglycans in interfibrillar substance to eliminate the adhesion between fiber bundles, which is illustrated in Fig. 2a; the other is that proteoglycans wrapping microfibrils and fibrils are destroyed, consequently, the bounds are loosened, and the microfibrils and fibrils are separated, which is illustrated in Fig. 2b.

\subsection{Glycosidase assisting unhairing}

On the early age, it is reported that glycosidases had the effect of unhairing because they might destroy the mucins around hair follicles [32, 33, 51, 52]. Even though the unhairing time was up to 3 days, the epidermis with intact hair was removed as sheets and the grain of pelt was very good. However, it was also reported that this kind of enzymes alone had no unhairing ability, and the observed unhairing effect might be from the protease components of the crude glycosidase preparations without purified, and the growth of microorganisms in the long treatment without any bactericide [31]. Furthermore, the crystalline enzymes, i.e. amylase and wheat 

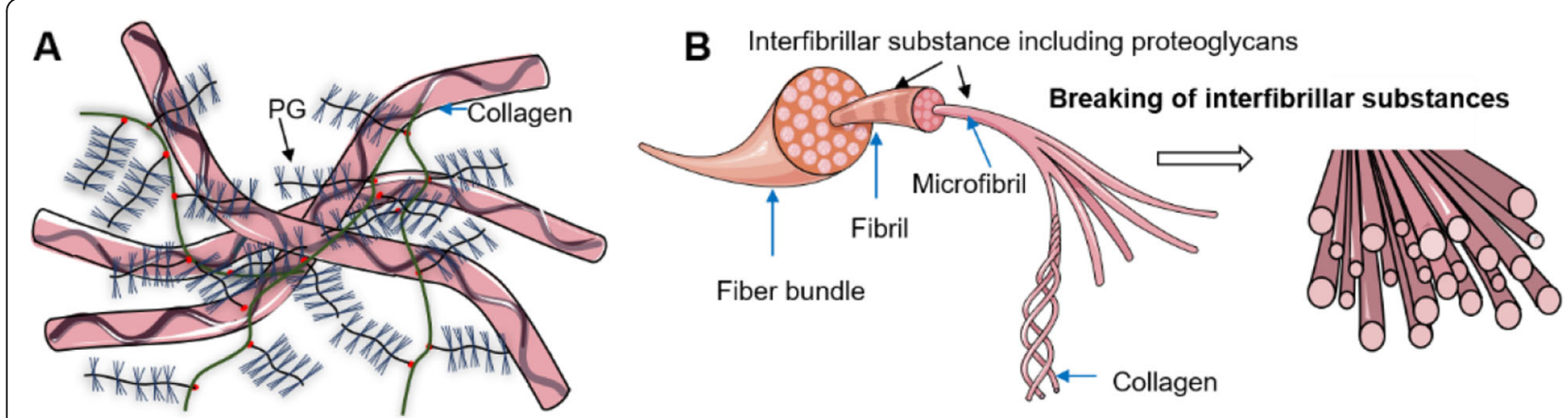

Fig. 2 The mechanism of glycosidase assisting opening-up fiber. a Large proteoglycan aggregates in interfibrillar substances; b Proteoglycans wrapping microfibrils, fibrils and fiber bundles

bran glycosylase, were used to remove hairs by the way of injecting enzymes into the skin, and the results showed that they couldn't dehair [53]. The penetration and reaction conditions of the injection method were quite different from that in the real leather manufacturing process, and the dosages of the pure enzymes were too low, hence, the results were controversial. Then it was found that amylase could assist protease unhairing but couldn't act alone through comparing the unhairing results from the "pure protease", the "pure amylase" and the mixture enzymes, respectively [54].

Enzyme unhairing is regarded as a cleaner method of removing hairs from skin, in which proteases are mainly used to break the protein substances between hair shaft and hair follicle, and between hair bulb and hair papilla to release the intact hair from skin, illustrated in Fig. 3.

Current enzyme unhairing technologies still mainly depend on proteases. The key problem is that it is difficult to achieve the complete removal of hairs while without leather grain loose and damaged. Because it is not easy for the proteases with a large molecular size to penetrate through the dense epidermis and basement membrane to arrive at the action points. Enzyme unhairing costs large dosage of protease and long unhairing time. Consequently, the collagen, especially in grain layer, are excessively enzymolysis.

Since the unwanted components of skin are complicated, the biotechnology of a single enzyme is not so ideal. The multi-enzymatic processes can improve the efficiency $[55,56]$. It is a feasible way using glycosidases to break the polysaccharides of interfibrillar substances, rather than only protease hydrolyzing proteins, to reduce the dosage of protease and make protease penetrate quickly, thus, hydrolysis effect on the collagen in grain layer is decreased. Based on this point of view, a rapid and integrated process of unhairing and fiber opening-up with the combination of proteases and glycosidases, i.e. amylases or galactosidases, was designed and conducted to replace the conventional liming, deliming and bating process, which offered an eco-friendly leather process with reduced pollution load, time and cost [57-59]. The related mechanism and unhairing effect of a protease and a glycosidase are illustrated in Fig. 4. The histological photos of skin stained by Periodic acid-Schiff and Alcian blue show that the PGs are almost completely removed after the unhairing process. The glyco-protein conjugates existing in the hair root sheaths, hair papillae and the basement membrane, can hold the root and negatively impact the penetration of proteases. The broken of the glyco-protein conjugates makes the hair root loose and shortens the time of protease penetration. Actually, penetration of protease costs $70 \%$ of unhairing duration [60], thus it can avoid the excessive hydrolysis of collagen in the grain layer by reducing the penetration time of protease.

Although the positive role of glycosidases on unhairing and fiber opening-up was related to the breaking of

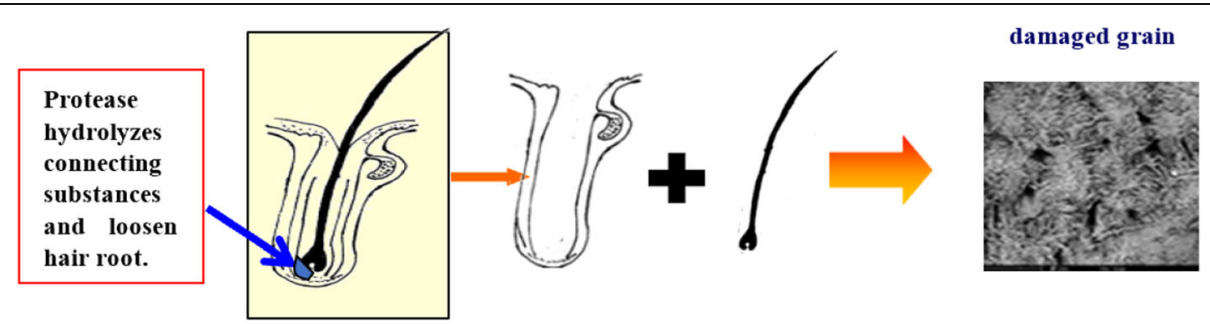

Fig. 3 The mechanism of protease unhairing 

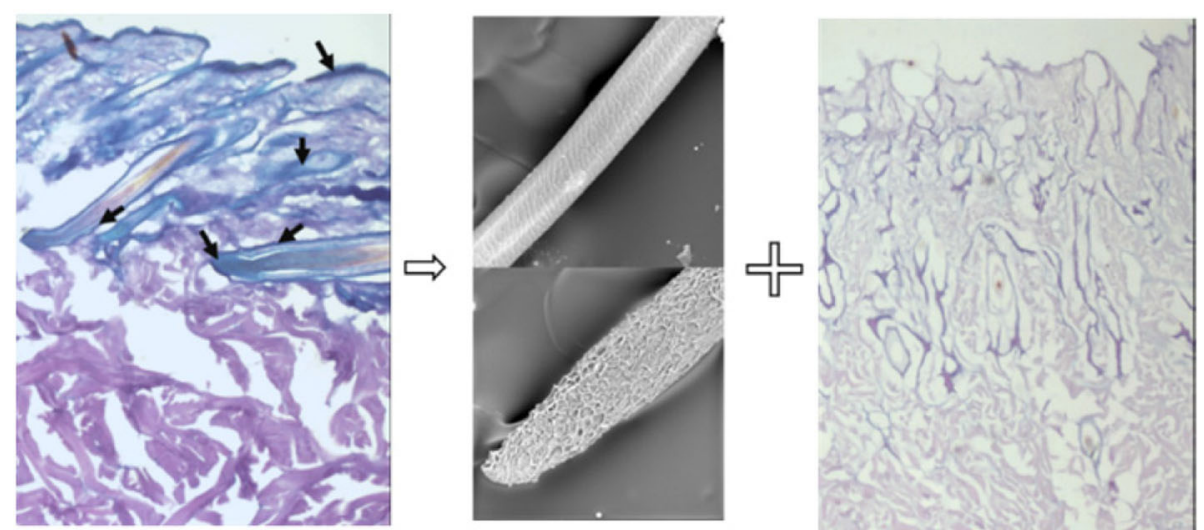

Fig. 4 The mechanism and unhairing effect of a protease and a glycosidase. The PGs (stained purple-blue which was indicated in the black arrow) in the hair root bulb, epidermis and surrounding the follicle and collagen fibers in the papillary layer were almost all removed after unhairing by protease and glycosidase.

decorin, a kind of PG in skin [61, 62], the mechanism was not yet fully elucidated. How to select the optimum glycosidase was still not clear. Most of the work only focus on trying to find the availability of a certain glycosidase. Because the composition and structure of glycoprotein conjugates are complicated, the mechanism of glycosidase acting on glyco-protein conjugates, especially, the requirement of substrate specificities to glycosidase, is not well understood. Nowadays, as the study of glycomics is a hotspot with the development of the related technologies. Hence, the constituents, structures and distribution of glyco-protein conjugates in the skin and their relationship with collagen or hair follicles become more and more clear. It is worth recognizing them to rethink of the more effective methods of removing them.

\section{Recognition of glyco-protein conjugates in skin}

Glyco-protein conjugates, the main components of skin interfibrillar substances, are composed of protein and polysaccharide. The saccharides are covalently linked to the protein by the $\mathrm{O}$-glycosidic bond or $\mathrm{N}$-glycosidic bond in the site of the serine, threonine or aspartic acid residue of the peptide chain, which is called O-linked saccharide or N-linked saccharide. According to the difference of protein and saccharide contents, they are divided into glycoprotein (GP) and proteoglycan (PG). Similarities and differences of PG and GP are summarized in Table 1. The properties of GPs which contain a few saccharides are more like those of common proteins. But the amount of saccharides accounts for higher than $50 \%$ in PG molecules, and the long chains of glycosaminoglycan (GAG) with high charge accumulation exhibit the property of higher adhesion and viscosity, consequently, most of them are difficult to be removed.

\subsection{Glycoproteins(GPs) in skin}

GPs are composed of long peptide chains conjugated with the branched oligosaccharides (commonly less than 15 saccharides) [63]. The main GPs in the skin are fibronectin (FN) and laminin (LN).

FNs are a kind of cold-insoluble dimeric glycoproteins with a high molecular weight of about $450 \mathrm{kDa}$, and the two similar subunits are covalently linked through disulfide bonds near the C-terminus. It contains $4.5 \%-9.5 \%$ of saccharide, and each subunit has seven N-linked oligosaccharide chains and one or two O-linked oligosaccharide chains. The non-glycosylated protein is more sensitive to proteases and high temperatures than the glycosylated one because the saccharide chains stabilize FNs against degradation. The glycosylation also alters the binding affinity of the protein to collagen fibrils. FN is fundamental for the formation and organization of the extracellular matrix. It is one of the earliest components of the extracellular matrix and provides a scaffold for deposition of the

Table 1 Similarities and differences of PG and GP

\begin{tabular}{|c|c|c|c|c|c|}
\hline Types & Composition & $\begin{array}{l}\text { Link } \\
\text { bridge }\end{array}$ & $\begin{array}{l}\text { Saccharide } \\
\text { content }\end{array}$ & $\begin{array}{l}\text { Saccharide } \\
\text { composition }\end{array}$ & Saccharide structure \\
\hline $\begin{array}{l}\text { GP }[63, \\
64]\end{array}$ & $\begin{array}{l}\text { Saccharide covalent binding to } \\
\text { protein }\end{array}$ & $\mathrm{O}-/ \mathrm{N}-$ & $<50 \%$ & $\begin{array}{l}\text { Branched } \\
\text { oligosaccharide }\end{array}$ & complicated \\
\hline $\begin{array}{l}P G[65, \\
66]\end{array}$ & $\begin{array}{l}\text { Protein covalent binding to } \\
\text { saccharide }\end{array}$ & $\mathrm{O}-/ \mathrm{N}-$ & $>50 \%$ & $\begin{array}{l}\text { Long unbranched } \\
\text { chain }\end{array}$ & $\begin{array}{l}\text { Disaccharide composed by hexosamine and } \\
\text { hexuronic acid }\end{array}$ \\
\hline
\end{tabular}


proteins, such as collagen molecules and heparan sulfate proteoglycans $[67,68]$. The interaction between FN and collagen or heparan sulfate proteoglycans mediates the denaturation of collagen and helps cell adhesion and the formation of microfilament bundles [69].

LNs are a kind of heterotrimeric glycoproteins with three different polypeptide chains, and their molecular weights are about $400-900 \mathrm{kDa}$. They are glycosylated in different amounts, ranging from $12 \%-32 \%$ [70]. The carbohydrate chains are $\mathrm{N}$-linked oligosaccharides which are composed of mannose, galactose and $\mathrm{N}$-acetylglucosamine. Laminins play an important part in providing the structure for the initial assembly of the basement membrane by selfpolymerization and the formation of filaments and layered sheets in the basement membrane. They are also the central adhesive proteins of the basement membrane to connect the adjacent cell layers [71].

Collagen can be decorated by oligosaccharides through the hydroxylysine of $\alpha$-chain of collagen molecule, thus regarded as a kind of GP, as shown in Fig. 5. The glucose and galactose residues are linked to the collagen to form the structure of 2-O- $\alpha$-glucosyl- $\beta$-O-galactosyl-2$\beta$-O-hydroxylysine. The collagen intermolecular centerto-center distances correlate with the extent of glycosylation of collagen. Thus, the extent of glycosylation influences the incorporation of collagen molecules into fibrils.

Even though the GPs in the skin are very important to the formation of collagen fibrils, fiber bundles and skin structure, and keeping the physiological functions, these materials are more similar to proteins rather than polysaccharides, hence, GPs are easier to be removed from the animal skin by common chemical methods. GPs are not the main acted objects by glycosidases in leather processing.

\subsection{Proteoglycans (PGs) in skin}

Different from GP, PG is made up of a peptide chain called core protein and several longer glycosaminoglycan (GAG) chains covalently linked to the peptide chain by the O-glycosidic bond or N-glycosidic bond. More than
$50 \%$ of saccharide content in PG and the special GAG chains make its character more like glycan rather than protein [63]. The long and unbranched GAG chain is linked by several to hundreds of repeated disaccharides units composed of a hexuronic acid and a hexosamine which are often sulfated or acetylated. This endows the PGs with enormous structure variations and multifarious functions. For example, GAGs can absorb large quantities of water and form solutions with high elasticity and viscosity because of the high molecular weight and many sulfated and acetyl groups.

According to the differences of the repeated disaccharide unit and the extent of sulfated, the GAG can be divided into 6 kinds: hyaluronic acid (HA), dermatan sulfate (DS), chondroitin sulfate (CS), keratin sulfate (KS), heparan sulfate (HS) and heparin. The structures of the basic disaccharide units are illustrated in Fig. 6 . DS, also called CSB, is from the isomerization of the Dglucuronic acid (D-GlcUA) of the disaccharide unit in CS into L-iduronic acid (IdoUA), and it often co-exists with CS [73]. HA and DS are the foremost components as they occupy about $90 \%$ of the GAGs in skin, and the content of HA is about twice as much as that of DS [63]. Hence, the HA and proteoglycans containing dermatan sulfate (DSPG) in the skin are the most noteworthy constituents in the leather-making processes.

According to the molecular weight and structure, PGs existing in the extracellular matrix of skin can be divided into two kinds: small molecule leucine-rich PGs, mainly including decorin and biglycan; and large aggregated PGs, mainly including perlecan and versican [65]. They will be elaborated further for comprehensive understanding as below.

\subsubsection{Small molecule leucine-rich proteoglycans (SLRPs)}

This kind of proteoglycans with lower molecular weight usually contain one or two long GAG chains covalently linked to the peptide chain (core protein) rich in leucine near the N-terminal through O-glycosidic bond. Besides, several short oligosaccharide chains are covalently combined with the core protein through the $\mathrm{N}$-glycosidic

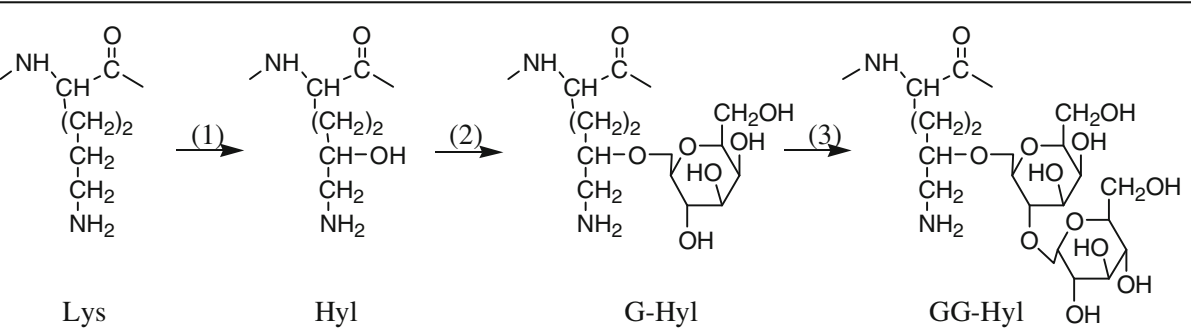

Fig. 5 Collagen decorated by oligosaccharide. Reaction 1 represents the hydroxylation of lysine in the collagen molecule; reaction 2 is the galactosylation of hydroxylysine; reaction 3 is the glucosylation of the galactosyl group. Reprinted from ref. [72], Copywright (2004), with permission from Portland Press, Ltd. 

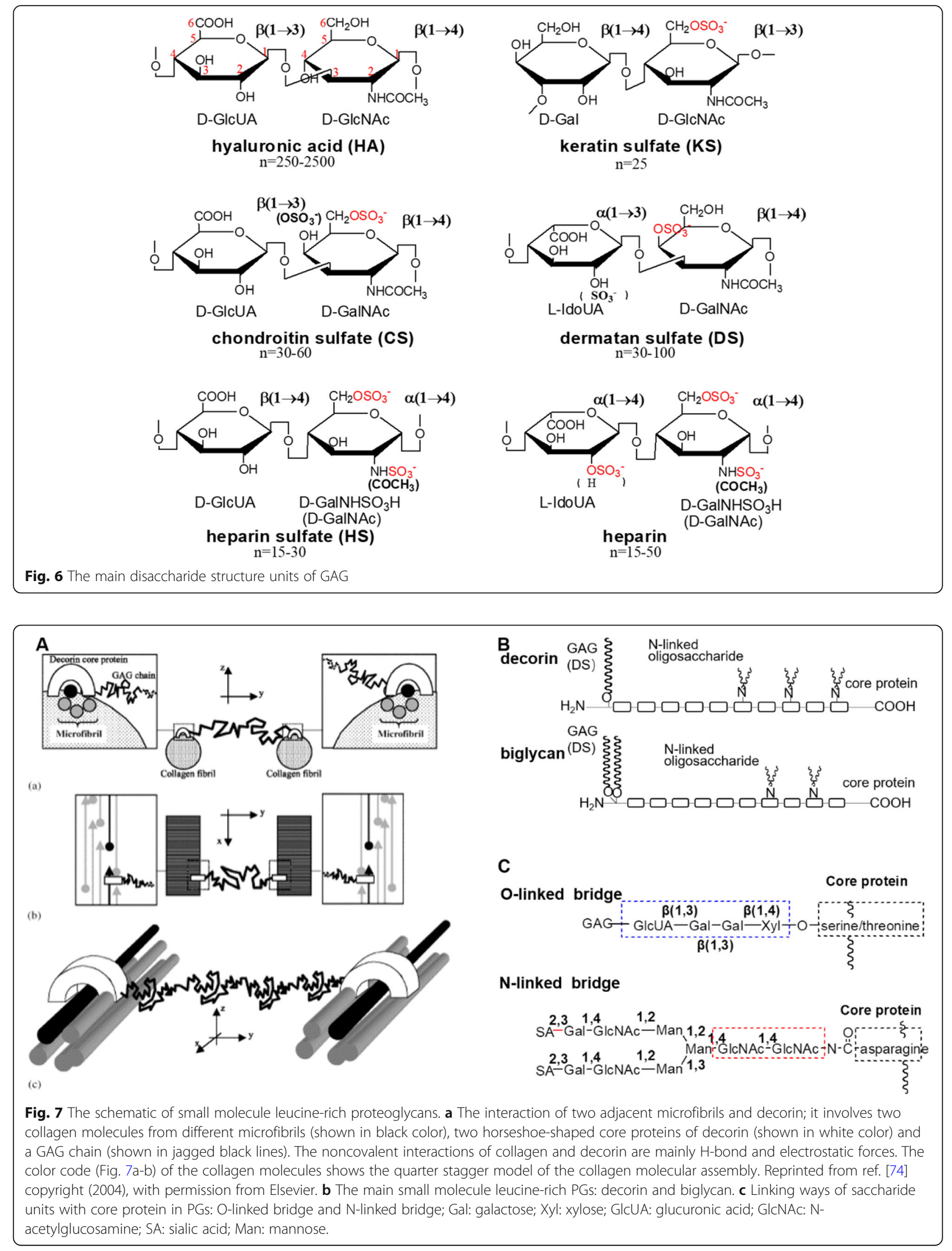
bond. Decorin and biglycan are typical examples of the family in the skin. Decorin and biglycan mainly exist in the basement membrane, hair follicles, around the lipid glands and between the collagen microfibrils, fibrils and fibers. The existence of which directly influences the effects of fiber opening-up and unhairing in leather processing, hence, it is necessary to understand their structures, properties, especially, their existing ways and their relationship with collagen fibers or hairs. The structures of which are illustrated in Fig. 7.

4.2.1.1 Relationship with collagen microfibrils The decorin and biglycan are closely related to the collagen fibers. Decorin is so named as it decorates the collagen I and collagen II. Among all different kinds of PGs, the content of decorin in the skin is the most abundant PG in the skin, about $0.4 \%$ of the weight of dried skin $[75,76]$. Biglycan is similar to decorin except for linking two GAG chains, which makes it possible for biglycan to bond with more collagen molecules than decorin [77]. Biglycan is known as dermatan sulfate proteoglycan-I (DSPG-I), and decorin is also named as dermatan sulfate proteoglycan-II (DSPG-II).

As illustrated in Fig. 7, the core protein of decorin which looks like a "horse-shoe" shape interacts with the collagen molecules in microfibrils through favorable $\mathrm{H}$ bond and electrostatic forces in the leucine-rich regions, and a GAG chain is covalently linked with the protein near the N-terminal. It is vertically distributed between two parallel collagenous microfibrils, consequently, the two microfibrils are connected [74]. The concave of the core protein may bond 4-6 collagen molecules, which means that the decorin can bundle several collagen molecules into microfibrils and make these molecules tightly interacted. Decorin is periodically distributed vertically in the "d" or "e" band of the periodic banding patterns of type I collagen. Biglycan competes with decorin in the same binding sites on collagen [78]. In a word, the core protein of decorin supplies a strong anchor for its elastic GAG chain, while the curved, folded and long-chain of GAG adjusts the distance of collagen fibrils. It was reported that the length of a GAG chain was approximately equal to the interfibrillar distance it spanned [79]. The curved and elastic GAG chain can help to adjust the distance between collagen fibrils under the external force. Studies on mice showed that the normal content of decorin and biglycan made the skin exhibit regular and compact collagen fibril arrangement; a lack of decorin and biglycan genes in mice or humans could lead to Ehlers-Danlos syndrome, manifesting as abnormal collagen binding, irregular fiber size, and reduced skin tensile strength [80].

Besides promoting the lateral binding of the original fibrils [81], decorin can also wrap the surfaces of collagen fibrils and bundles to protect them against proteases and collagenases [82, 83]. As shown in Fig. 7, GAG chains with high charge density coating fibrils like a sheath help the collagen preventing from protease and collagenase hydrolysis. If decorins are broken by chondroitinase or express at a low level resulting from the UV radiation to the skin, the collagen is more easily hydrolyzed by the matrix metalloproteinases and other proteases [83]. It can be deduced that the destruction of the proteoglycan wrapping around the collagen fibers can not only break the constraint of collagen fiber bundles but also reduce the resistance of collagen molecules to enzymatic hydrolysis, and thus it will accelerate the fiber opening-up during leather processing.

4.2.1.2 Relationship with hair follicle Decorin is highly expressed in the epidermis, hair follicle epithelial cells and dermal papilla cells in the anagen phase of hair [84, 85]. PG participates in cell-ECM and cell-cell adhesion, cell differentiation, and envelops follicles and helps to fix the hair shafts. It also modulates follicular cycling and morphogenesis as the deficiency and abnormality of these PGs will cause hair loss and hair follicle abnormality [85]. During the unhairing process, the content of decorin also reduces with hair removal. Similar to decorin, biglycan content differs in different periods of the growth cycle of hair. Thus, the destruction of biglycan and decorin may promote hair root loosening and hair removal.

4.2.1.3 Structures of decorin and biglycan As mentioned before, the decorin and biglycan are closely related to fiber opening-up and unhairing. Therefore, it is fundamental to study their structures and properties to find effective ways to remove them in leather manufacture.

Decorin consists of one core protein, covalently combining one GAG chain and several oligosaccharide chains, shown in Fig. 7b. The core protein contains 1012 leucine-rich regions and a high content of proline and alkali amino acids, thus it has a high isoelectric point of 9.8; its molecular weight is about $40 \mathrm{kDa}$, while the molecular weight of decorin is about $90-140 \mathrm{kDa}$. The amino acid sequence of the core protein forms repeating $\beta$-folds and helical regions. There is a disulfide bond linking the $\mathrm{N}$-terminal and $\mathrm{C}$-terminal of the core protein, making it form a horse-shoe shape. The concave formed by the $\beta$-folds is thought to form the primary surface for the interactions with collagen molecules, and the repeating leucine-rich areas provide the high-affinity binding sites for collagen [74]. The GAG chain, mainly DS or CS, is covalently linked to the serine or threonine residue near the $\mathrm{N}$-terminal of the core protein by the tetra-saccharide unit of glucuronyl-galactosyl-galactosylxylosyl (GlcUA-Gal-Gal-Xyl). Besides, there are three oligosaccharide chains covalently connected with the 
core protein through N-linked bridge on the sites of No. 188, 232 and 273 amino acid.

Biglycan is a $200-350 \mathrm{kDa}$ proteoglycan consisting of a $45 \mathrm{kDa}$ core protein and two GAG chains of DS and CS. Apart from the number of GAG chains, the structure is exactly similar to the decorin as well. The GAG chains of biglycan contain $71 \%$ of iduronic acid while decorin contains $78 \%$ of iduronic acid [86].

\subsubsection{Large aggregated $P G s$}

Large aggregated PGs with huge molecular weight consist of large core proteins (more than $100 \mathrm{kDa}$ ) and numerous GAG chains. The typical PG aggregates existing in collagen bundles of the dermis is shown in Fig. 8a. Many GAG chains covalently combine with a core protein to form a "bottle brush" structure, and then the several brushes are fixed on a long main chain of hyaluronic acid (HA) through the link proteins to form a larger aggregate. Other typical aggregated PGs that exist in the ECM include perlecan and versican.

4.2.2.1 Perlecan Perlecan monomer contains a group of modular proteins that carry three long GAG chains of heparan sulfate (HS), as shown in Fig. 8b. It is widespread in the basement membrane and looks like a string of pearls. The GAG chains with each approximate $70-100 \mathrm{kDa}$ are attached to a core protein of a molecular weight of about $470 \mathrm{kDa}$. Perlecan is a potential linker of laminin and collagen IV networks in the basement membrane and responsible for maintaining the basement membrane integrity in regions and mechanical stress. The core protein and HS chains of perlecan can modulate matrix assembly, cell proliferation, lipoprotein binding and cell adhesion $[87,88]$.

4.2.2.2 Versican Versican monomer is a specific component of the basement membrane, highly expressed around hair follicles, glands, vasculatures and in the reticular dermis during scar formation. About 12-15 GAG chains of CS are assembled in a core protein. Several versican monomers bind to a HA chain through the link proteins by non-covalent interaction to form an aggregate. Its gel-like properties can enable it to immobilize ECM proteins or restrict their actions, and it can also block their activities by a steric hindrance to protect them from matrix metalloproteinase, or act as a reservoir for their delayed-release [89-91]. In the skin, versican can colocalize with elastin and influence the forming of elastic fibers [92].

The HA mentioned above is an acidic mucopolysaccharide. It is a simple and special GAG composed of the repeated disaccharide units of glucuronic acid and acetylglucosamine. The saccharide units of HA are neither sulfated nor covalently linked with a protein. HA is not strictly a proteoglycan as it can exist in the state of dissociation without a core protein, but it can combine with several PGs through link proteins to form an aggregate. Different from other GAGs generally consisted of less than 300 monosaccharides, hyaluronan contains higher than 100,000 glycosyl groups with a molecular weight of $1.0 \times 10^{6}-8.0 \times 10^{6}$. In the solution, the hyaluronan molecule is in a state of irregular curl and forms a colloid even in a low concentration, which exhibits high water-retaining property. Because it is noncovalently linked to other materials, the connections of link proteins are easily destroyed resulting in the departure of PGs from the aggregate under acidic and alkaline conditions in the leather making process. According to the study of Alexander, more than $90 \%$ of hyaluronan can be removed in the soaking process in the alkali condition [31].

Although the PG content is reduced with the processes of soaking, unhairing, liming, bating and pickling, even with glycosidases, such as amylase treatment, PGs can't be fully removed. When the leather is dried, the skin fibers are still cemented

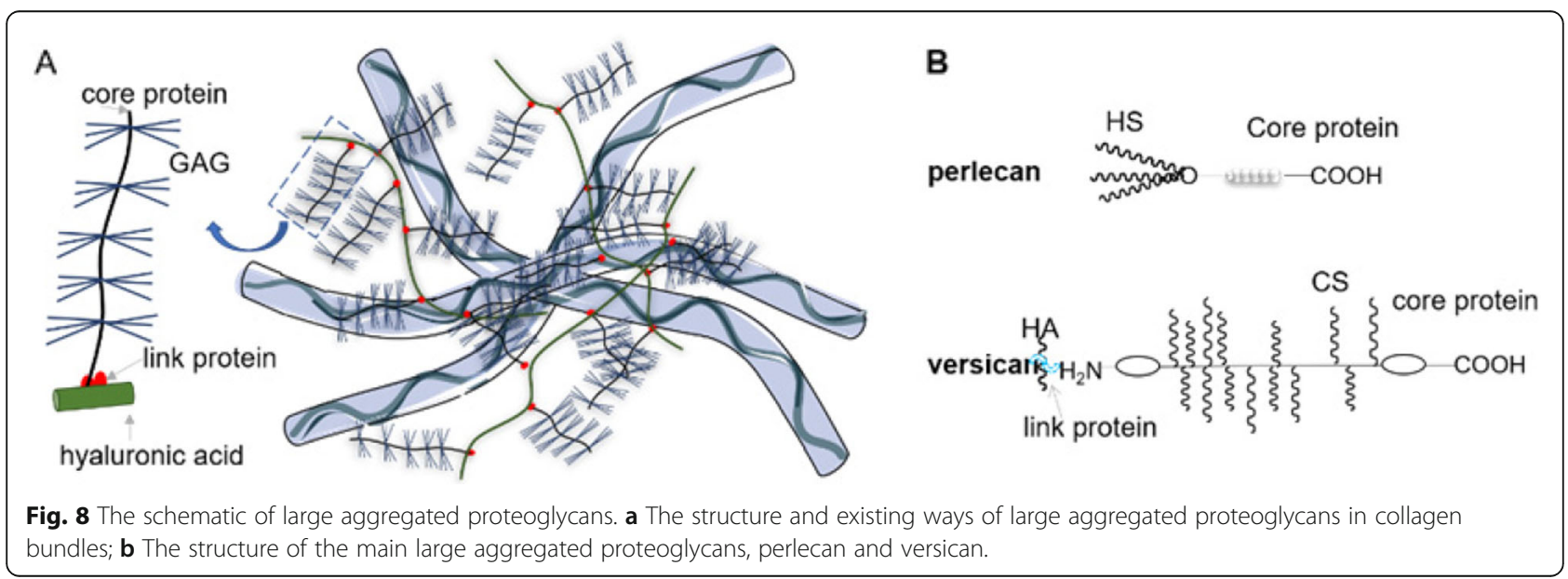


together by the remained sticky glycoconjugates, consequently, the well opening-up of fibers cannot be maintained, resulting in the decrease of leather softness.

\section{Possible glycosidases suitable for breaking glyco-protein conjugates in leather making}

As mentioned before, the glyco-protein conjugates, such as GPs, PGs, GAGs and so on, are the essential components of animal skin, and take an important physiological role to living animals. Most of them also play very important roles in assembling and forming collagen fibrils and fibrous bundles and fixing hairs in hair follicles. Hence, they should be removed to improve unhairing and fiber opening-up in leather processing. Some of them, such as saccharide compounds with small molecular weight, the hyaluronan, and the GPs can be easily removed according to the mentioned reports, and the GPs are not the objects of concerning herein. As far as the PGs with complicated structures are concerned, there are three approaches to destroy their molecular structures: one is breaking the link bond, mainly the O-linked bridge illustrated in Fig. 7c, between the GAG and core protein to release the GAG chains; the second one is cutting the core protein chain into several peptide fragments with the whole GAG chains; the third one is cleaving the glycosidic bonds of the GAG chain into small molecule oligosaccharides, even sugar units. Theoretically, the above three approaches can be implemented by suitable acids, alkalis and enzymes treatment. But in fact, the breaking down of PGs is limited under the relatively mild conditions of leather processing due to the tolerance of collagen protein to strong acid, alkaline and high temperature. Obviously, the enzymatic hydrolysis is a wise choice.

According to the composition and structure of PG, two kinds of enzymes can be used to decompose it. Proteases can disintegrate the PG through hydrolyzing the core protein in the site (8) showed in Fig. 9a. It was reported that a protease produced from Bacillus cereus could hydrolyze the core protein of decorin into peptide chains and showed a good unhairing effect [93]; papain in company with trypsin hydrolyzed core protein of decorin into short peptides, but the surviving components
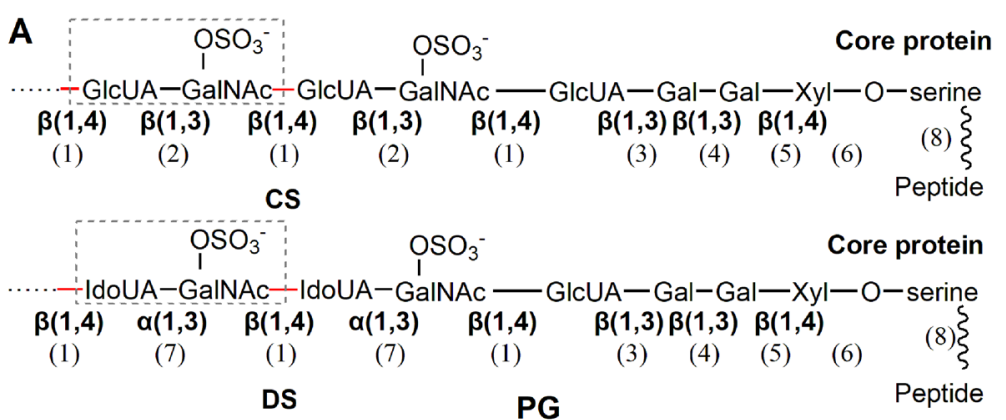

B O-linked oligosaccharide

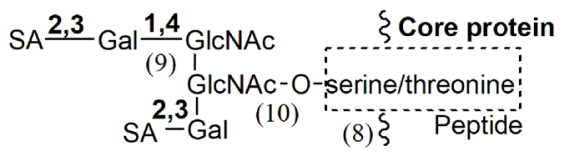

N-linked oligosaccharide

PG
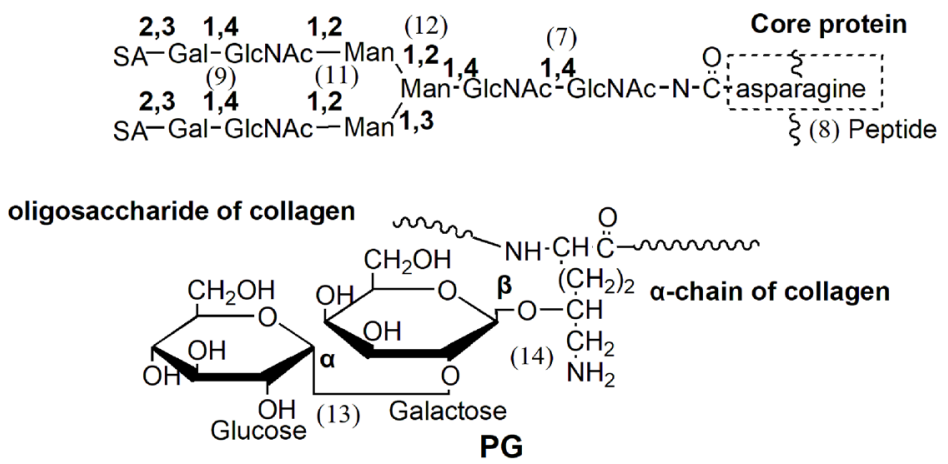

Fig. 9 Possible glycosidase hydrolysis sites in the glyco-protein conjugates in skin 
in skin might still act as adhesives after the leather was dried [82]. Moreover, the glycosylated protein is not easy to be attacked by proteases because of the cover and wrap effect of long GAG chains [93, 94]. The application of proteases may also lead to the excessive damage of collagen protein. Hence, the application of glycosidase is the better choice for breaking PG.

The glycosidases are a big family with over 200 kinds of glycosidases, which are specific to multifarious glycosidic bonds, different sugar types, configurations of sugar, linkages of glycosidic bond and glycoside ligands [95]. Therefore, there is a huge utilization potentiality to develop cleaner, cheaper and more high-efficient technologies to remove the glyco-protein conjugates based on the proper glycosidases.

But we need to answer the question: what kind of glycosidases can break the glyco-protein conjugates especially the hard-to-remove PGs in the skin? According to the special structure of PG, there are two kinds of acting sites of glycosidases: the glycosidic bonds of GAG chains and the link unit between core protein and GAG, as shown in Fig. 9a.

As mentioned above, the main GAG chains of PG are DS and CS in the skin, so the possible cutting sites are the glycosidic bonds of the main chain of GAG. The GAG may be cut on the site (1), site (2) and site (7), shown in Fig. 9, by hyaluronan lyase, chondroitin $A B C$ lyase, chondroitin AC lyase, chondroitin B lyase, chondroitin $C$ lyase, $\beta$-galactosidase, keratanase and heparin lyase, respectively, and corresponding oligosaccharides including eight, six, four saccharides, even disaccharide are obtained [93]. All these enzymes are endoglycosidases which can randomly hydrolyze the specific glycosidic bond in the GAG chain $[96,97]$. A series of exo-glycosidases, such as $\beta$-glucuronidase [98], $\alpha$ iduronidase [99], $\beta-\mathrm{N}$-acetylhexosaminidase [100], $\alpha-\mathrm{N}$ acetylglucosaminidase [101] and $\beta$-galactosidase [102] may degrade the oligosaccharide into monosaccharides. But these exo-glycosidases only attack the nonreducing end of the sugar chains of substrates to release di- or monoccharides from the polysaccharide.

The other possible cutting sites are the glycosidic bonds of the link bridge. The PG may be cut into the long GAG chain and peptide chain by $\beta$-glucuronidases [103], $\beta$-galactosidases [104] and $\beta$-xylosidases [105] in the site (3), site (4), site (5). The hydrolysis product of $\beta$ glucuronidase is the GAG with the end of GlcA. $\beta$ galactosidase specially hydrolyzes the $\beta$-galactoside bond of Gal- $\beta 1,3-G a l$ rather than the Gal-Xyl bond in the linkage region between the core protein and GAG moiety to liberate long polysaccharide chains with the end of Gal. Products of $\beta$-xylosidase are intact GAG chains with Xyl at the reducing end. Long-chain GAGs are much more readily cleaved by the enzyme than shorter saccharide chains.
Figure $9 \mathrm{~b}$ also shows that the possible acting sites and kinds of glycosidases against the other glycosidic bonds in GP and in oligosaccharide of PG. The short N-linked oligosaccharide chain of PG may be hydrolyzed in the site (7), site (9), site (11) and site (12), by the $\beta$ galactosidases, $\beta$-acetyl-glucosaminidases and mannosidases. The short oligosaccharide chains of GP can also be hydrolyzed in the site (9), site (10), site (13) and site (14) by glycosidases including glucanases, $\alpha / \beta$ - galactosidases, $\beta$-acetyl-glucosaminidases and mannosidases $[106$, 107]. These hydrolysis ways take place in the lysosome under the synergistical actions of several kinds of glycosidases.

These glycosidases showed in Fig. 9 are named according to their substrate specificities, but they exist in the organisms with mixtures and cooperate with the metabolism of PGs and GPs. It's hard to purify them and it is impractical to be widely used in the leather industry. Hence, the industrial glycosidase preparations possibly suitable for leather making should be further considered. Actually, most of the commercial preparations are the mixtures of glycosidases with different specificities, for example, the commercial cellulase is a mixture of the endo-1,4- $\beta$-glucanase, exo-1,4- $\beta$-glucanase and $\beta$-1,4- glucosidase, which might cooperate to hydrolyze the disaccharide units of GAG and the link bridge. Table 2 shows the possible acting sites and products of some typical commercial glycosidases hydrolyzing glyco-protein conjugates in skin. Xylanases and galactosidases may hydrolyze the link bridge between the GAG chain and core protein of PG, and the possible products are long GAG chain and core protein. GAG is probably hydrolyzed into disaccharide units by glucanases and cellulases specific to the $\beta$ glucosidic bond. The oligosaccharide chains in GP may be cut by $\alpha$-galactosidases and $\alpha$-amylases specific to $\alpha$ glucosidic bond and $\alpha$-galactosidic bond, respectively. Hence, their effects are not obvious.

Considering the diversity of glycosidic bonds in the polysaccharide components of skin and the strict specificities of glycosidases, the application of multiple glycosidases may be a wise choice. For example, the mixture of $\beta$-acetyl-galactosaminidases and xylosidases may break the GAG into oligosaccharides even disaccharides which are easy to be removed from the skin. Based the above analysis of the related mechanisms, it is necessary to develop a method to evaluate the effects of glycosidases on the polysaccharide components of skin, to screen the correct enzyme and optimize the formula of the compound enzyme. Among these commercial glycosidases, xylanase, cellulase and glucanase are multi-components with the advantages of different kinds of substrates specificity, synergistic hydrolysis effect of multi-enzymes, large output, and low cost. They might can be widely used in the beamhouse of leather manufacturing. 
Table 2 The possible acting sites and products of some typical commercial glycosidases hydrolyzing glyco-protein conjugates in skin

\begin{tabular}{|c|c|c|c|c|}
\hline $\begin{array}{l}\text { Commercial } \\
\text { glycosidases }\end{array}$ & Specificity & $\begin{array}{l}\text { Acting } \\
\text { objectives }\end{array}$ & Possible products & Resource \\
\hline Glucanase & $\begin{array}{l}\beta- \\
\text { glucoside }\end{array}$ & $P G$ & 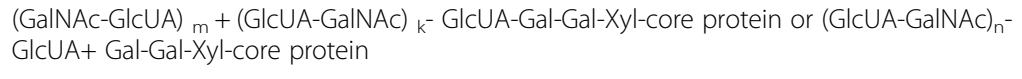 & \\
\hline Cellulase & $\begin{array}{l}\beta \text { - } \\
\text { glucoside }\end{array}$ & $P G$ & & [108] \\
\hline Xylanase & $\beta$-xyloside & $P G$ & (GlcUA -GalNAc) k- GlcUA-Gal-Gal-Xyl + core protein & {$[105]$} \\
\hline$\beta$-galactosidase & $\begin{array}{l}\beta \text { - } \\
\text { galactoside }\end{array}$ & $P G / G P$ & $\begin{array}{l}\text { (GlcUA [ldoUA]-GalNAc) n- GlcUA-Gal+ Gal-Xyl-core protein } \\
\text { Glu-gal+ collagen }\end{array}$ & $\begin{array}{l}{[104]} \\
{[109]}\end{array}$ \\
\hline a-galactosidase & $\begin{array}{l}\text { a- } \\
\text { galactoside }\end{array}$ & GP & - & {$[50]$} \\
\hline a-amylase & $\begin{array}{l}\text { a- } \\
\text { glucoside }\end{array}$ & GP & Glucose+gal-collagen & - \\
\hline
\end{tabular}

Besides the correct choice of glycosidases, the optimization of application conditions is also very important. At present, the optimum $\mathrm{pH}$ value of most of the glycosidases are in acid or neutral ranges, which hinders the widely usage of glycosidases in beamhouse under the alkali condition. Therefore, it is necessary for developing alkali glycosidases to meet the requirements of leather manufacturing.

What's more, the combination of glycosidases with proteases may act synergistically in the way of breaking both polysaccharide and protein components of PG. Because the saccharide chain and protein chain protect each other from hydrolysis by glycosidase or protease. Application of protease and glycosidase mixtures might be one of the main directions of biotechnology in leather manufacturing.

\section{Conclusions}

The glycoconjugates, including GPs, PGs, and GAGs are the essential components of animal skin. The glycoconjugates play very important roles in assembling and forming collagen fibrils and fibrous bundles, fixing hairs in hair follicles. The exist of them negatively impacts the effectiveness of unhairing and fiber opening-up. Hence, they should be removed in leather processing, and the method of enzymatic hydrolysis is a wise choice.

Based on the recognition of the kinds, compositions, structures and functions of typical glyco-protein conjugates in skin, and their relationship to skin and hair follicle structure, especially the kinds, compositions, structures and functions of typical glyco-protein conjugates in skin, the enzymolysis approaches, possible glycosidases and their acting sites are analyzed. There are two kinds of cutting sites in PGs for glycosidases: the glycosidic bonds of GAG chains and the link unit between core protein and GAG. The possible endoglycosidases for cutting the glycosidic bonds of GAG chain randomly include hyaluronan lyase, chondroitin
ABC lyase, chondroitin AC lyase, chondroitin B lyase, chondroitin $C$ lyase, $\beta$-galactosidase, keratanase and heparin lyase. The possible exo-glycosidases for hydrolyzing the oligosaccharide chains include $\beta$-glucuronidases, $\beta$ acetyl-galactosaminidases and $\alpha$-iduronidases. $\beta$ glucuronidases, $\beta$-galactosidases and $\beta$-xylosidases may cut the glycosidic bonds of the link bridge between the GAG chain and core protein. Other glycosidic bonds in GP and oligosaccharide chains of PG may also be cut by $\alpha / \beta$-galactosidases, $\beta$-acetyl-glucosaminidases and mannosidases.

In industrial applications, the possible acting sites of some typical commercial glycosidases in glyco-protein conjugates of skin are speculated. Glucanase, xylanase, cellulase and $\beta$-galactosidase may have better effectiveness than $\alpha$-amylase and $\alpha$-galactosidase.

Considering the diversity of glycosidic bonds in the polysaccharide components of skin and the strict specificities of glycosidases, the multi-enzyme system, i.e. the synergistic effects of several different glycosidases or glycosidases and proteases may be the better approach. In order to quickly screen the correct enzymes and optimize the formula of compound enzymes, it is very necessary to establish a method to evaluate the effects of glycosidases on the polysaccharide components of skin. What's more, it is necessary to develop alkali glycosidases to meet for the $\mathrm{pH}$ requirement of beamhouse operations, and to optimize the application conditions of glycosidase.

\section{Abbreviations}

PG: Proteoglycan; GAG: Glycosaminoglycan; GP: Glycoprotein; ECM: Extracellular matrix; BM: Basement membrane; DS: Dermatan sulfate; CS: Chondroitin sulfate; HS: Heparan sulfate; HA: Hyaluronic acid, hyaluronan; DSPG: Dermatan sulfate proteoglycan; FN: Fibronectin; LM: Laminin; SA: Sialic acid; Man: Mannose; GlcUA: Glucuronic acid; GlcNAc: N-acetyl-glucosamine; GalNAc: N-acetyl-galactosamine; IdoUA: Iduronic acid; Gal: Galactose;

Glc: Glucose

\section{Acknowledgements}

The authors acknowledge Chunxiao Zhang and Sadaqat Ali Chattha for their suggestions and English grammar corrections. 


\section{Authors' contributions}

P B made contributions to the conception and design of this paper and performed the revision of the manuscript. L F collected references and wrote the initial draft. PB and LF contributed equally to this article. Z X collected references about glycosidase assisting soaking and fiber opening. G M collected references about unhairing. $\mathrm{L} Z$ collected the information about some typical commercial glycosidases. The authors read and approved the final manuscript.

\section{Funding}

Thanks for the financial support from the National Key R\&D Program of China (2017YFB0308402)

\section{Competing interests}

The authors declare that they have no competing interests.

\section{Author details}

'Key Laboratory of Leather Chemistry and Engineering of Ministry of Education, Sichuan University, Chengdu 610065, China. ${ }^{2}$ National Engineering Laboratory for Clean Technology of Leather Manufacture, Sichuan University, Chengdu 610065, China. ${ }^{3}$ Xuzhou Hoffen chemicals Co., LTD, Xuzhou 221200, China

Received: 5 January 2020 Accepted: 22 April 2020

\section{Published online: 22 May 2020}

\section{References}

1. Kanagaraj J, Senthilvelan T, Panda RC, et al. Eco-friendly waste management strategies for greener environment towards sustainable development in leather industry: a comprehensive review. J Clean Prod. 2015;89:1-17. https://doi.org/10.1016/j.jclepro.2014.11.013.

2. Choudhary RB, Jana AK, Jha MK. Enzyme technology applications in leather processing. Indian J. Chem Techn. 2004;11:659-71.

3. Valeika $V$, Beleška $K$, Valeikienè $V$, et al. An approach to cleaner production: from hair burning to hair saving using a lime-free unhairing system. J Clean Prod. 2009:17(2):214-21. https://doi.org/10.1016/j.jclepro.2008.04.010.

4. Thanikaivelan P, Rao JR, Nair BU, et al. Recent trends in leather making: processes, problems, and pathways. Crit Rev Environ Sci Technol. 2007;35(1): 37-79. https://doi.org/10.1080/10643380590521436.

5. Pillai P, Mandge S, Archana G. Statistical optimization of production and tannery applications of a keratinolytic serine protease from Bacillus subtilis P13. Process Biochem. 2011;46(5):1110-7. https://doi.org/10.1016/j.procbio. 2011.01.030

6. Anzani C, Prandi B, Buhler S, et al. Towards environmentally friendly skin unhairing process: a comparison between enzymatic and oxidative methods and analysis of the protein fraction of the related wastewaters. J Clean Prod. 2017;164:1446-54. https://doi.org/10.1016/j.jclepro.2017.07.071.

7. Sujitha P, Kavitha S, Shakilanishi S, et al. Enzymatic dehairing: a comprehensive review on the mechanistic aspects with emphasis on enzyme specificity. Int J Biol Macromol. 2018;118:168-79. https://doi.org/10. 1016/j.jibiomac.2018.06.081.

8. Song J, Tao W, Chen W. Kinetics of enzymatic unhairing by protease in leather industry. J Clean Prod. 2011;19(4):325-31. https://doi.org/10.1016/j. jclepro.2010.10.011.

9. Dettmer A, Cavalli É, Ayub MAZ, et al. Environmentally friendly hide unhairing: enzymatic hide processing for the replacement of sodium sulfide and deliming. J Clean Prod. 2013;47:11-8. https://doi.org/10.1016/j.jclepro. 2012.04.024

10. Khandelwal HB, More SV, Kalal KM, et al. Eco-friendly enzymatic dehairing of skins and hides by C. brefeldianus protease. Clean Technol. Envir. 2015;17(2): 393-405. https://doi.org/10.1007/s10098-014-0791-y.

11. Li Z. The chemistry and histology of animal skins. Beijing: China Light Industry Press. 2010

12. lozzo RV. Methods in molecular biology: proteoglycan protocols [G] Totowa: Humana Press Inc. 2001

13. Sharphouse JH. Leather technician's handbook. 2rd ed. Northampton: Leather Producers' Association. 1995.

14. Reed CC, lozzo RV. The role of decorin in collagen fibrillogenesis and skin homeostasis. Glycoconj J. 2002;19(4-5):249-55. https://doi.org/10.1023/A 1025383913444
15. Mcgrath JA, Eady RAJ, Pope FM. Anatomy and organization of human skin. In: Tony Burns MB, editor. Rook's textbook of dermatology. New Jersey: Blackwell Publishing Ltd. 2004.

16. Elias PM, Feingold KR. Epidermis as a dynamic interface. Old Herborn University Seminar Monograph 28: The epidermis of man: co-existing with commensals; Herborn, Germany. 2015. p. 1-17.

17. Elias PM. Structure and function of the stratum corneum permeability barrier. Drug Dev Res. 1988;13:97-105.

18. Tzu J, Marinkovich MP. Bridging structure with function: structural, regulatory, and developmental role of laminins. Int J Biochem Cell Biol. 2008;40(2):199-214. https://doi.org/10.1016/j.biocel.2007.07.015.

19. Noonan DM, Fulle A, Valente $P$, et al. The complete sequence of perlecan, a basement membrane heparan sulfate proteoglycan, reveals extensive similarity with laminin a chain, low density lipoprotein-receptor, and the neural cell adhesion molecule. J Biol Chem. 1991;266(34):22939-47 http:// www.jbc.org/content/266/34/22939.

20. Edmonds R. Proteolytic depilation of lambskins [D]. Palmerston North: Massey University. 2008.

21. Cantera CS. Hair-saving unhairing process: part 1. Epidermis and the characteristics of bovine hair. Journal of the Society of Leather Technologies and Chemists. 2001;85:1-5.

22. Cantera CS, Garro ML, Goya L, et al. Hair saving unhairing process: part 6 stratum corneum as a diffusion barrier: chemical-mechanical injury of epidermis. Journal of the Society of Leather Technologies and Chemists. 2004;88:121-31.

23. Reich G. From collagen to leather - the theoretical background. Ludwigshafen: BASF. 2007.

24. Heidemann E. Fundamentals of leather manufacturing, vol. 649. Darmstadt: Eduard Roether KG. 1993.

25. Galbraith H. Fundamental hair follicle biology and fine fibre production in animals. Animal. 2010;4(09):1490-509. https://doi.org/10.1017/ S175173111000025X

26. Chajra $H$, Auriol $D$, Joly $F$, et al. Reactivating the extracellular matrix synthesis of sulfated glycosaminoglycans and proteoglycans to improve the human skin aspect and its mechanical properties. 2016;9:461-72. https://doi. org/10.2147/CCID.S116548.

27. Li Y. Research of interfibrillary materials of north chinese pigskin-change during producing process of soft upper leather and corrected grain in the beamhouse. J Shangdong Light Indust Institute. 1990;4(2):21-7.

28. Wang $X$, Chang $X$. Influence of the different pickling process on removing the interfibrillary non-fibrous components during the production of furskin. J Northwest Institute Light Indust. 1990;8(4):31-6 117.

29. Pan J, Chang X, Yu K. The changes of dermatan sulphate proteoglycan of sheep skin during 3350 acid protease bating process. J Northwest Institute Light Indust. 1988:6(4):40-6.

30. Alexander KTW, Haines BM, Walker M. Influence of proteoglycan removal on opening-up in beamhouse. J Am Leather Chem As. 1986; 81(4):85-100.

31. Reed R. The significance of the mucoids of hides and skins in the limeyard. J Soc Leath Tech Ch. 1953:37:75-81.

32. Cordon TC. Unhairing of hides and skins by amylase preparations. J Am Leather Chem As. 1955;50:270-4.

33. Burton $D$, Reed $R$, Flint $F$. The unhairing of hides and skins without lime and sulphide. The use of mucolytic enzymes. J Soc Leath Tech Ch. 1953;37:82-7.

34. Bowes C, Elliott, et al. B.I.m.r.a. Lab Reports. 1951;30:172.

35. Barbachina BT. Application of enzymes in leather making. Beijing: China Light Industry Press. 1965.

36. Melville W, Deasy C. Effect of alpha amylase treatment on the tensile properties of steerhide and leather. J Am Leather Chem As. 1977;72(6):216-29.

37. Novozymes. Enzymatic treatment for the leather process [P]. WO2010043709A1. 2010

38. Dettmer A, Anjos PSD. Special review paper: enzymes in the leather industry. J Am Leather Chem As. 2013;108(4):146-58

39. Tozan M, Conviton AD, Evans CS. Studies on the mechanism of enzymatic degradation of dung. J Am Leather Chem As. 2002;97:178-88

40. Covington $A$, Evans $C$, Ullah $M$. Fermentation of an enzyme mixture containing cellulase xylanase and laccase by cultivating while rot fungi for cleaning animal skin in production of leather [P]. UK2003778007. 2003.

41. Jayanthi D, Victor JS, Chellan R, et al. Green processing: minimising harmful substances in leather making. Environ Sci Pollut R. 2019:26(7):6782-90. https://doi.org/10.1007/s11356-018-04111-z. 
42. He X, Wang Y, Zhou J, et al. Suitability of pore measurement methods for characterizing the hierarchical pore structure of leather. J Am Leather Chem As. 2019;114:41-7 https://www.researchgate.net/publication/331714685.

43. Madhan B, Rao JR, Nair BU. Studies on the removal of inter-fibrillary materials part I: removal of protein, proteoglycan, glycosaminoglycans from conventional beamhouse process. J Am Leather Chem As. 2010;105:145-9.

44. Madhan B, Rao JR, Nair BU. Studies on the removal of inter-fibrillary materials part II: removal of protein, proteoglycan, glycosaminoglycans from biobased pre-tanning process. J Am Leather Chem As. 2010;105:181-8.

45. Saravanabhavan S, Aravindhan $\mathrm{R}$, Thanikaivelan $\mathrm{P}$, et al. A source reduction approach: integrated bio-based tanning methods and the role of enzymes in dehairing and fibre opening. Clean Technol Envir. 2004;7(1):3-14. https:// doi.org/10.1007/s10098-004-0251-1.

46. Yang $H$, Lan L, Weihua $D$, et al. Bio-enzyme based fiber opening technology for greener leather processing. China Leather. 2013;45(15):16-22. https://doi. org/10.13536/j.cnki.issn1001-6813.2013.15.012.

47. Lan L, Yang $H$, Weihua $D$, et al. Molecular mechanism in process of fiber opening-up. China Leather. 2013;42(3):10-2. https://doi.org/10.13536/j.cnki. issn1001-6813.2013.03.009.

48. Lan L, Yang $H$, Weihua $D$, et al. Molecular mechanism in process of fiber opening-up. China Leather. 2013:42(5):15-8 22.

49. Durga J, Ranjithkumar A, Ramesh R, et al. Replacement of lime with carbohydrases-a successful cleaner process for leather making. J Clean Prod. 2016;112:1122-7. https://doi.org/10.1016/j.jclepro.2015.07.018.

50. Punitha V, Kannan P, Saravanabhavan S, et al. Enzymatic removal of melanin in enzyme based dehairing and fibre opening. J Am Leather Chem As. 2008;103(7):203-8.

51. Durga J, Ranjithkumar A, Ramesh R, et al. Rapid fiber opening process for skins: an approach for fail-safe chemical-free process. J Am Leather Chem As. 2015:110(1):7-12

52. Bose SM, Krishna M, Das BM. Mechanism of unhairing skins and hides by means of certain proteolytic or amylolytic enzymes. J Am Leather Chem As. 1955;50:192-7

53. Yates JR. Studies in depilation. VI. Correlation of activity of depilatory enzyme systems with their activity against simple substrates. J Am Leather Chem As. 1968:63(8):474-9.

54. Zeng $\mathrm{YH}$, Kong $\mathrm{X}$, Wang $\mathrm{YN}$, et al. Effective component in a-amylase preparation for unhairing. J. Am. Leather Chem. As. 2013;108:86-92 https:// www.researchgate.net/publication/262726989.

55. de Souza FR, Gutterres M. Application of enzymes in leather processing: a comparison between chemical and coenzymatic processes. Braz J Chem Eng. 2012;29(3):473-81.

56. Song J. Studies on hair removal technology and mechanism of glycosidase and protease [D]; Wuxi: Jiangnan University. 2008.

57. Jayakumar GC, Sathish M, Aravindhan R, et al. Studies on the use of bifunctional enzyme for leather making. J Am Leather Chem As. 2016;111(12): 455-60 https://alcajournal.com/index.php/abstracts/2016/december-2016/.

58. Thanikaivelan P, Bharath CK, Saravanabhavan S, et al. Integrated hair removal and fiber opening process using mixed enzymes. Clean Technol Envir. 2007;9(1):61-8. https://doi.org/10.1007/s10098-006-0053-8.

59. Gladstone Christopher J, Ganesh S, Palanivel S, et al. Cohesive system for enzymatic unhairing and fibre opening: an architecture towards eco-benign pretanning operation. J Clean Prod. 2014;83:428-36. https://doi.org/10.1016/ j.jclepro.2014.07.039.

60. Song $Y$, Wu $S$, Yang $Q$, et al. Factors affecting mass transfer of protease in pelt during enzymatic bating process. J Leather Sci Eng. 2019;1(1). https:// doi.org/10.1186/s42825-019-0007-7.

61. Saravanan P, Shiny Renitha T, Gowthaman MK, et al. Understanding the chemical free enzyme based cleaner unhairing process in leather manufacturing. J Clean Prod. 2014;79:258-64. https:/doi.org/10.1016/j.jclepro.2014.05.022.

62. Shakilanishi S, Shanthi C. Specificity studies on proteases for dehairing in leather processing using decorin as model conjugated protein. Int J Biol Macromol. 2017;103:1069-76. https://doi.org/10.1016/j.ijbiomac.2017.05.134

63. Kornfeld R, Kornfeld S. Structure of glycoproteins and their oligosaccharide units. In: Lennarz W J editor, The Biochemistry of Glycoproteins and Proteoglycans; Berlin: Springer-Verlag. 1980. p. 1-31.

64. Zhang $\mathbf{W}, \mathbf{M u ~ H}$, Zhang $\mathrm{A}$, et al. A decrease in moisture absorptionretention capacity of N-deacetylation of hyaluronic acid. Glycoconj J. 2013 30(6):577-83. https://doi.org/10.1007/s10719-012-9457-3.

65. Mecham RP. The extracellular matrix: an overview [G]. Dordrecht: Springer Heidelberg; 2011.
66. Kjellén L, Lindahl U. Proteoglycans structures and interactions. Annu Rev Biochem. 1991;60:443-75.

67. Hynes RO. The extracellular matrix: not just pretty fibrils. Science. 2009;326: 1216-9. https://doi.org/10.1126/science.1176009.

68. Leikina E, Mertts MV, Kuznetsova N, et al. Type I collagen is thermally unstable at body temperature. Proc Natl Acad Sci U S A. 2002;99(3):1314-8. https://doi.org/10.1073/pnas.032307099.

69. Erat MC, Slatter DA, Lowe ED, et al. Identification and structural analysis of type I collagen sites in complex with fibronectin fragments. Proc Natl Acad Sci U S A. 2009;106(11):4195-200. https://doi.org/10.1073/pnas.0812516106.

70. Kumar AP, Nandini CD, Salimath PV. Structural characterization of N-linked oligosaccharides of laminin from rat kidney: changes during diabetes and modulation by dietary fiber and butyric acid. FEBS J. 2011;278(1):143-55. https://doi.org/10.1111/j.1742-4658.2010.07940.x.

71. Li S, Harrison D, Carbonetto S, et al. Matrix assembly, regulation, and surviva functions of laminin and its receptors in embryonic stem cell differentiation. J Cell Biol. 2002;157(7):1279-90. https://doi.org/10.1083/jcb.200203073.

72. Yamauchi M, Sricholpech M. Lysine post-translational modifications of collagen. Essays Biochem. 2012;52:113-33. https://doi.org/10.1042/ BSE0520113.

73. Chen RL. Mechanisms of glycosaminoglycan assembly on proteoglycan cores [D]. Irvine: University of California; 2003.

74. Vesentini S, Redaelli A, Montevecchi FM. Estimation of the binding force of the collagen molecule-decorin core protein complex in collagen fibril. J Biomech. 2005;38(3):433-43. https://doi.org/10.1016/j. jbiomech.2004.04.032

75. Scott JE. Structure and function in extracellular matrices depend on interactions between anionic glycosaminoglycans. Pathol Biol (Paris). 2001; 49(4):284-9.

76. Li Y, Liu Y, Xia W, et al. Age-dependent alterations of decorin glycosaminoglycans in human skin. Sci Rep-UK. 2013;3(1). https://doi.org/10. 1038/srep02422.

77. Scott PG, Dodd CM, Tredget EE, et al. Immunohistochemical localization of the proteoglycans decorin, biglycan and versican and transforming growth factor-p in human post-burn hypertrophic and mature scars. Histopathology. 1995:26:423-31.

78. Schã Nherr E, Witsch-Prehm P, Harrach BR, et al. Interaction of biglycan with type I collagen. J Biol Chem. 1995;270(6):2776-83. https://doi.org/10.1074/ jbc.270.6.2776

79. Orgel J, Eid A, Antipova O, et al. Decorin core protein (decoron) shape complements collagen fibril surface structure and mediates its binding. PLoS One. 2009;4(9). https://doi.org/10.1371/journal.pone.0007028.

80. Nikolovska K, Renke JK, Jungmann O, et al. A decorin-deficient matrix affects skin chondroitin/dermatan sulfate levels and keratinocyte function. Matrix Biol. 2014:35:91-102. https://doi.org/10.1016/j.matbio.2014.01.003.

81. Keene DR, San Antonio JD, Mayne R, et al. Decorin binds near the C terminus of type I collagen. J Biol Chem. 2000;275(29):21801-4. https://doi. org/10.1074/jbc.C000278200

82. Kronick PL, landola SK. Persistence of minority macromolecules of hide through the beamhouse. III. Persistence of decorin. J Am Leather Chem As. 1998;93(5):148-55.

83. Li Y, Xia W, Liu Y, et al. Solar ultraviolet irradiation induces decorin degradation in human skin likely via neutrophil elastase. PLoS One. 2013; 8(8):1-8. https://doi.org/10.1371/journal.pone.0072563.

84. Jing J, Wu X, Li Y, et al. Expression of decorin throughout the murine hair follicle cycle: hair cycle dependence and anagen phase prolongation. Exp Dermatol. 2014;23(7):486-91. https://doi.org/10.1111/exd.12441.

85. Inui S, Itami S. A newly discovered linkage between proteoglycans and hair biology: decorin acts as an anagen inducer. Exp Dermatol. 2014;23(8):547-8. https://doi.org/10.1111/exd.12471.

86. Tufvesson E, Malmström J, Marko-Varga G, et al. Biglycan isoforms with differences in polysaccharide substitution and core protein in human lung fibroblasts. Eur J Biochem. 2002;269:3688-36936.

87. Breitkreutz D, Koxholt I, Thiemann K, et al. Skin basement membrane: the foundation of epidermal integrity-BM functions and diverse roles of bridging molecules nidogen and perlecan. Biomed Res Int. 2013;2013:1-16. https://doi.org/10.1155/2013/179784.

88. Behrens DT, Villone D, Koch $M$, et al. The epidermal basement membrane is a composite of separate laminin- or collagen IV-containing networks connected by aggregated perlecan, but not by nidogens. J Biol Chem. 2012;287(22):18700-9. https://doi.org/10.1074/jbc.M111.336073. 
89. Wight TN. Provisional matrix: a role for versican and hyaluronan. Matrix Biol. 2017;60-61:38-56. https://doi.org/10.1016/j.matbio.2016.12.001.

90. Kinsella MG, Bressler SL, Wight TN. The regulated synthesis of versican, decorin, and biglycan: extracellular matrix proteoglycans that influence cellular phenotype. Crit Rev Eukar Gene. 2004;14(3):203-34. https:/doi.org/ 10.1615/CritRevEukaryotGeneExpr.v14.i3.40.

91. Sorrell JM, Carrino DA, Baber MA, et al. Versican in human fetal skin development. Anat Embryol. 1999;199:45-56.

92. Isogai Z, Aspberg A, Keene DR, et al. Versican interacts with fibrillin-1 and links extracellular microfibrils to other connective tissue networks. J Biol Chem. 2002;277:4565-72. https://doi.org/10.1074/jbc.M110583200.

93. Takagaki K, Kakizaki I. Degradation of Glycosaminoglycans. In: Kamerling JP editor, Comprehensive Glycoscience. The Netherlands: Elsevier. 2007. p. 171-92.

94. Yamamoto K. Endoenzymes. In: Endo T, Seeberger PH, Whart G, et al., editors. Glycoscience: biology and medicine. Tokyo: Springer Japan; 2014. p. $1-8$.

95. Coutinho PM, Henrissat B. Carbohydrate-active enzymes: an integrated database approach. In: Gilbert HJ, Davies G, Henrissat B, and Svensson B. editors, Recent advances in Carbohydrate Bioengineering; Cambridge: The Royal Society of Chemistry. 1999. p. 3-12.

96. Zhang W. The biochemical research technology of glycoconjugates. 2 rd ed. Hangzhou: Zhejiang University Press; 1999.

97. Aldema-Ramos ML, Liu C. A novel system of removing decorin, a minor proteoglycan of bovine hides, to improve the quality of leather. J Am Leather Chem As. 2010;105:222-8.

98. Nakamura T, Takagaki K, Majima M, et al. Demonstration of $\mathrm{N}$ acetylchondrosine-degrading $\beta$-glucuronidase in rabbit liver. FEBS Lett 1988; 234(1): 91-94. https://doi.org/10.1016/0014-5793(88)81310-3.

99. Ohshita T, Sakuda H, Nakasone S, et al. Purification, characterization and subcellular localization of pig liver a-L-iduronidase. Eur J Biochem. 1989; 179(1):201-7. https://doi.org/10.1111/j.1432-1033.1989.tb14541.x.

100. Izumi T, Suzuki K. Neutral hydrolases of rat brain preliminary characterization and developmental changes of neutral $\beta$-N-acetylhexosaminidases. Biochimica et Biophysica Acta (BBA) - Enzymol. 1980;615(2):402-13. https:// doi.org/10.1016/0005-2744(80)90507-0.

101. Zhao KW, Neufeld EF. Purification and characterization of recombinant human alpha-N-acetylglucosaminidase secreted by Chinese hamster ovary cells. Protein Expr Purif. 2000;19(1):202-11. https://doi.org/10.1006/prep.2000. 1230.

102. Cheetham PS, Dance NE. The separation and characterization of the methylumbelliferyl $\beta$-galactosidases of human liver. Biochem J. 1976;157(1): 189-95. https://doi.org/10.1042/bj1570189.

103. Endo M, T Akagaki K, Nakamura T. Endoglycosidases acting on the linkage region between the core protein and glycosaminoglycan chains of proteoglycans: endo- $\beta$-glucuronidase, endo- $\beta$-xylosidase, and end- $\beta$ galactosidase. In: Handbook of endoglycosidases and Glycoamidases Boca Raton; 1992. p. 105-32

104. Takagaki K, Nakamura T, Takeda Y, et al. A new endo- $\beta$-galactosidase acting on the Galß1-3Gal linkage of the proteoglycan linkage region. J Biologival Chem. 1992;267(26):18558-63.

105. Takagaki K, Kon A, Kawasaki H, et al. Isolation and characterization of Patnopecten mid-gut gland endo- $\beta$-xylosidase active on peptidochondroitin sulfate. J Biol Chem. 1990;256(2):854-60.

106. Ashida H, Kato T, Yamamoto K. Degradation of glycoproteins. In: Kamerling JP editor, Comprehensive Glycoscience. The Netherlands: Elsevier. 2007: $171-92$.

107. Yamamoto K. Microbial endoglycosidases for analyses of oligosaccharide chains in glycoproteins. J Biochem. 1994;1 16(2):229-35. https://doi.org/10. 1093/oxfordjournals.jbchem.a124510.

108. Takagaki K, Iwafune M, Kakizaki I, et al. Cleavage of the xylosyl serine linkage between a core peptide and a glycosaminoglycan chain by cellulases. J Biol Chem. 2002;277(21):18397-403. https://doi.org/10.1074/jbc.M111985200.

109. Zhang J, Cheng P, Pu K. Recent advances of molecular optical probes in imaging of $\beta$-galactosidase. Bioconjug Chem. 2019;30(8):2089-101. https:// doi.org/10.1021/acs.bioconjchem.9b0039.

\section{Publisher's Note}

Springer Nature remains neutral with regard to jurisdictional claims in published maps and institutional affiliations.

\section{Submit your manuscript to a SpringerOpen ${ }^{\circ}$ journal and benefit from:}

- Convenient online submission

- Rigorous peer review

- Open access: articles freely available online

- High visibility within the field

- Retaining the copyright to your article

Submit your next manuscript at $\boldsymbol{\nabla}$ springeropen.com 